\title{
Changes in the elevation and extent of two glaciers along the Yanglonghe river, Qilian Shan, China
}

\author{
SHANGGUAN Donghui, LIU Shiyin, DING Yongjian, ZHANG Yingsong, LI Jing, \\ LI Xiangying, WU Zhen
}

State Key Laboratory of Cryospheric Science, Cold and Arid Regions Environmental and Engineering Research Institute, Chinese Academy of Sciences, Lanzhou 730000, China

E-mail:dhguan@Izb.ac.cn

\begin{abstract}
We use topographic maps, historical data, multispectral satellite data and real-time kinematic GPS data to analyze glacier area, length and ice-elevation changes of two glaciers in the central Qilian Shan, China, between 1956 and 2007. We find that the fronts of Yanglonghe glacier No. 1 (5Y432A1) and Yanglonghe glacier No. 5 (5Y432A5) have retreated by $266.5 \pm 37.1 \mathrm{~m}\left(5.2 \pm 0.73 \mathrm{~m} \mathrm{a}^{-1}\right)$ and $181.4 \pm 37.1 \mathrm{~m}\left(3.6 \pm 0.73 \mathrm{~m} \mathrm{a}^{-1}\right)$ respectively, and that this retreat accelerated after 1999. During the study period, the glacier areas decreased by $\sim 4.1 \%$ and $15.9 \%$ respectively. In addition, spatially non-uniform thinning, which averaged $20.2 \pm 11 \mathrm{~m}\left(0.4 \pm 0.22 \mathrm{ma} \mathrm{a}^{-1}\right)$ and $16.9 \pm 11 \mathrm{~m}$ $\left(0.33 \pm 0.22 \mathrm{~m} \mathrm{a}^{-1}\right)$ in the ablation areas of 5 Y432A1 and 5Y432A5 respectively, is observed using digital elevation models constructed using data from 1956, 1977 and 2007. The ice-volume depletion from 5 Y432A1 $\left(2.91 \times 10^{7} \mathrm{~m}^{3}\right)$ was 2.7 times greater than from the smaller 5 Y432A5 $\left(1.08 \times 10^{7} \mathrm{~m}^{3}\right)$. Based on records from nearby Tuole weather station, increasing annual temperatures are principally responsible for the observed glacier thinning and retreat.
\end{abstract}

\section{INTRODUCTION}

Melting of ice in glaciers and polar ice caps is believed to significantly raise sea levels (Kaser and others, 2006; Meier and others, 2007). Understanding changes in glacier length, areal extent and mass balance is thus important for understanding past climates and evaluating the contribution of glaciers to modern sea levels (Oerlemans, 2005; Meier and others, 2007). Glacier meltwater also plays an important role as a source of fresh water in some arid and semi-arid areas, where it supports daily life and the development of agriculture, livestock and industry (Yao and others, 2004; Ding and others, 2006). To understand the impacts of glacier changes, a small sample of measured glaciers is adequate, and this sample can be used to extrapolate from values for a particular glacier region to more global estimates (Hoelzle and others, 2003; Arendt and others, 2006; Haeberli and others, 2007). In recent decades, studies of glaciers have improved due to novel, rapid and relatively inexpensive techniques such as remote sensing and aerial photography (Paul and others, 2004; Kargel and others, 2005; Liu and others, 2006), Geographic Information System (GIS) software and GPS technology (Kääb and others, 2002; Paul and others, 2002; Kargel and others, 2005). Several studies have measured changes in glacier surface elevation using combinations of remotesensing and GPS technologies (Rivera and Casassa, 1999; Rignot and others, 2003; Berthier and others, 2004; King, 2004; Rivera and others, 2005; Howat and others, 2007; Berthier and Toutin, 2008).

It has been suggested that the mid-latitude Asian glaciers have retreated continuously since the 1990s as a result of global warming (Liu and others, 2003, 2006; Ding and others, 2006; Shangguan and others, 2006; Ye and others, 2006). However, due to the remote location and wide distribution of these glaciers, monitoring has been sparse in northwest China, especially with respect to ice-thickness and -volume changes, which have been poorly sampled in the field. At present, only 5 of China's 46377 glaciers have had their mass balance directly (but discontinuously) measured in the field since 1958, and only 246 glaciers around the world have been closely monitored in this manner (Braithwaite, 2002). Another problem is that the time series for this monitoring have been short (no longer than about 20 years), except for Ürümqi glacier No. 1, which has been monitored for $\sim 45$ years (Ye and others, 2005). Thus, only a limited dataset is available from longterm glacier observations.

Monitoring using remote-sensing images has indicated that glaciers in the west Qilian Shan have tended to retreat during the past 50 years, (Liu and others, 2003; Ding and others, 2006). However, glacier changes in the central and east Qilian Shan are presently unknown. To provide data on glaciers in this region of China, we chose Yanglonghe glacier No. 1 (World Glacier Monitoring Service ID 5Y432A1) and Yanglonghe glacier No. 5 (5Y432A5) $\left(39^{\circ} 13^{\prime} \mathrm{N}, 98^{\circ} 33^{\prime} \mathrm{E}\right)$, which originate on the northern slope of Suzhulian peak in the central Qilian Shan. These glaciers had total areas of 4.44 and $1.70 \mathrm{~km}^{2}$ respectively in 1956, and total lengths of 5.80 and $2.50 \mathrm{~km}$ (Fig. 1) (Wang and others, 1981). The Lanzhou Institute of Glaciology and Cryopedology (the Cold and Arid Regions Environmental and Engineering Research Institute) worked on these two glaciers in 1977, and produced a topographic map at a scale of 1:16000 (Xie and others, 1985). In the following 30 years, however, the two glaciers were not monitored again until our survey from 13 to 15 August 2007.

Here we report the results of our study of changes in ice elevation and glacier extent based on historical data from 1956 and 1977, and GPS real-time kinematic (GPS-RTK) data obtained in August 2007, supplemented by remotesensing images from 1999 and 2007. 


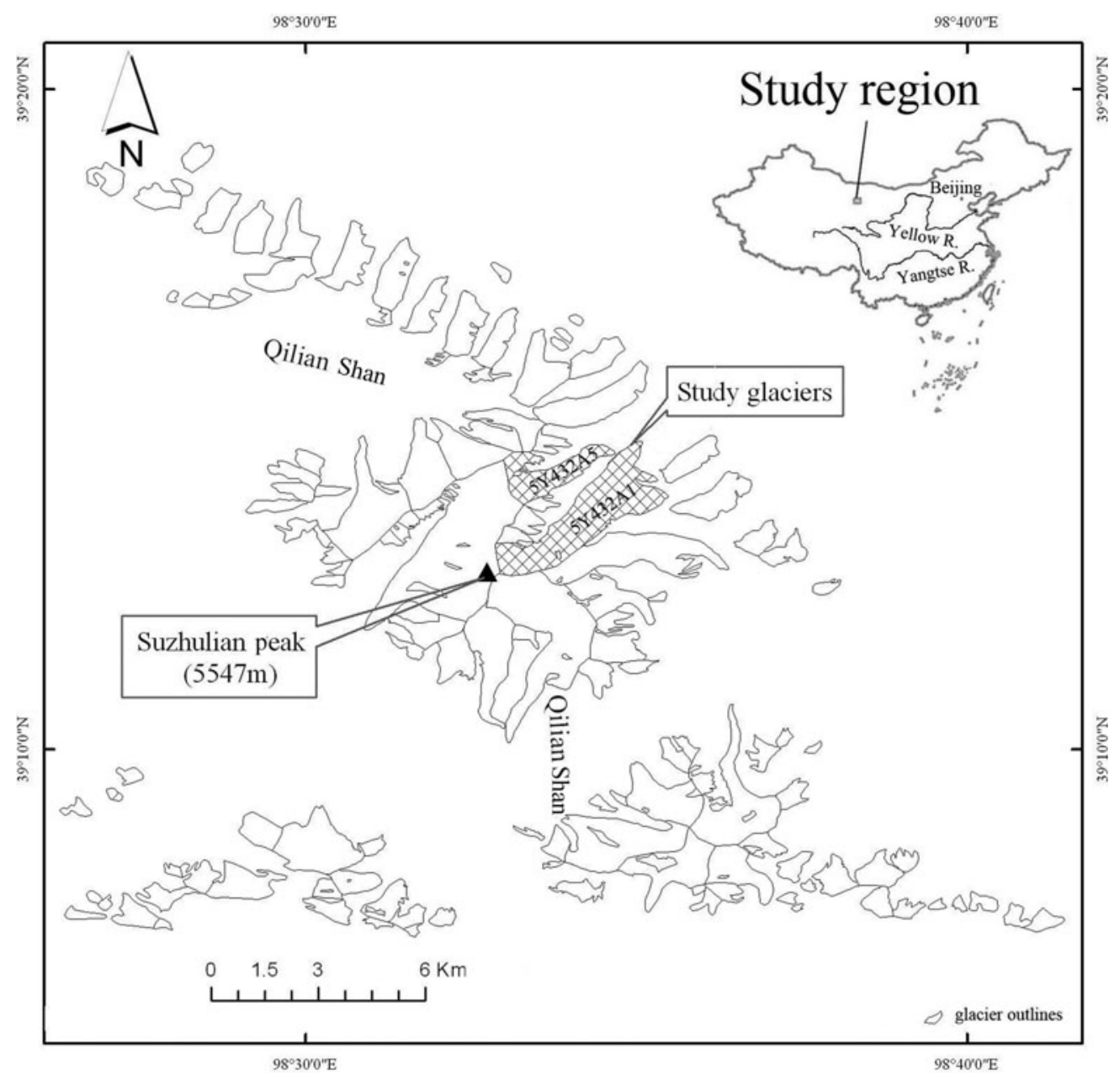

Fig. 1. The location of the two Yanglonghe glaciers in the present study (5Y432A1 and 5Y432A5).

\section{DATA AND METHODS}

\section{GPS data}

We performed GPS-RTK surveys of 5Y432A1 and 5Y432A5 from 13 to 15 August 2007 (Table 1). The survey regions covered glacial valleys with a total area of $\sim 1.44$ and $0.64 \mathrm{~km}^{2}$ respectively (Fig. 2 d), amounting to $32.4 \%$ and $37.6 \%$ of the total areas of the glaciers in 1956 .
The observation techniques consisted of RTK and static positioning (Fig. 2). For the static positioning, six Unistrong E650 dual-frequency receivers were used (Fig. 2a). Eight points were occupied for GPS data generation with a $5 \mathrm{~s}$ observation rate over at least 1 hour, to obtain precise position coordinates with cm-level accuracy using Unistrong LandTop 2.0.5.1 software. Among those points, there were two known points which were included in the China

Table 1. Data sources

\begin{tabular}{|c|c|c|c|c|c|c|}
\hline Data source & Date & Path-row & Resolution / scale & $\begin{array}{c}\mathrm{RMSE}^{\S} \\
\mathrm{m}\end{array}$ & $\begin{array}{c}\text { DEM }^{\top} \text { error } \\
\mathrm{m}\end{array}$ & Measurements \\
\hline Topographic map & 1956 & - & $5 \mathrm{~m} / 1: 50000^{\ddagger}$ & & $11-19^{\|}$ & Area, length and elevation \\
\hline Photogrammetry map & Sept. 1977 & - & $1 \mathrm{~m} / 1: 16000^{\ddagger}$ & 5.2 & $<2.0$ & Area, length and elevation \\
\hline Landsat ETM* & 23 Sept. 1999 & $135-33$ & $14.25 \mathrm{~m}$ & 12.8 & - & Area, length \\
\hline CBERS- $2^{\dagger}$ & 17 Nov. 2007 & $19-56$ & $19.7 \mathrm{~m}$ & 16.8 & - & Area, length \\
\hline GPS measurements & 13-15 Aug. 2007 & - & $0.3 \mathrm{~m}$ & & $<0.3$ & Area, length and elevation \\
\hline
\end{tabular}

*Enhanced Thematic Mapper.

${ }^{\dagger}$ China-Brazil Earth Resources Satellite-2.

According to the criteria of the State Bureau of Surveying and Mapping of China, the ground resolution of maps at scales of $1: 16000$ and $1: 50000$ is approximately 1 and $5 \mathrm{~m}$, respectively.

${ }^{\S}$ Root-mean-square error.

'Digital elevation model.

"SBSM (2007). The systematic errors of DEM1956 were $<11 \mathrm{~m}$ over slopes of $<15^{\circ}$ and $<19 \mathrm{~m}$ over slopes of $>25^{\circ}$. 

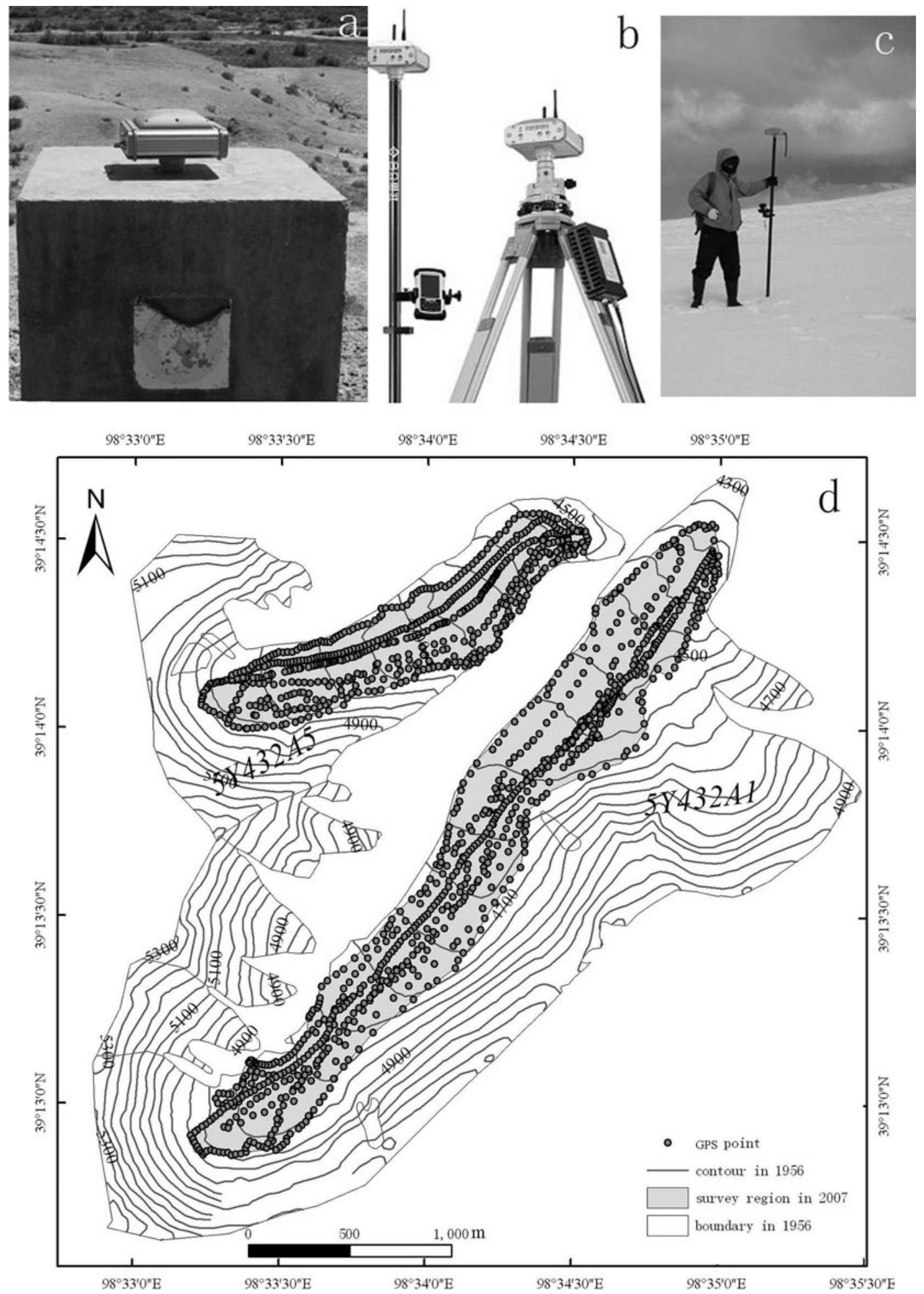

Fig. 2. GPS-RTK survey in the study region. (a) The national control point was surveyed in static survey by GPS. (b) The reference station and mobile station were surveyed in RTK model. (c) Surface points were collected by mobile station. (d) Map of the surface points.

Geodetic Coordinate System 2000 (CGCS2000). All points were measured using two independent baselines to provide enough redundancy to perform a least-squares adjustment. Thus, 14 baselines were generated by the 8 points, each (except for one) no longer than $20 \mathrm{~km}$.

For the RTK survey, five Unistrong E650 dual-frequency GPS receivers were used. The points shown in Figure $2 d$ were obtained in RTK mode, with four receivers carried by four researchers, and the fifth receiver (used as the base station for differential correction of post-processing) installed on a rocky outcrop. All GPS measurements were carried out with distances between the kinematic and base measurements no greater than $5 \mathrm{~km}$. The sampling was carried out using stop-and-go survey techniques (Fig. 2c); areas near ice cliffs were not surveyed because of dangerous walking conditions. We collected a total of 837 topographic points on 5 Y $432 \mathrm{~A} 1$ and 615 on 5 Y432A5. The data are presented in CGCS2000 format.

The precision of our GPS measurements is affected by measurement errors and by errors arising from the coordinate 
transformation. The standard error of the GPS devices is $0.01 \mathrm{~m} \pm 1 \mathrm{ppm}$ (horizontal error) and $0.02 \mathrm{~m} \pm 1 \mathrm{ppm}$ (vertical error) under the survey and signal reception conditions. However, surveys of surfaces in RTK differential mode will typically lead to a horizontal and vertical survey error of $0.10-0.30 \mathrm{~m}$ for geodetic-quality GPS receivers (Rivera and others, 2005), so we cite $0.30 \mathrm{~m}$ as the positioning error. In order to compare these data with previous digital elevation models (DEMs), we interpolated the GPS data to a $5 \mathrm{~m}$ contour interval using the cubic sample function of the South CASS 7.0 software (China) to generate DEM2007, with a pixel resolution of $30 \mathrm{~m}$.

\section{Topographic and photogrammetric maps from 1956 and 1977}

We used a map derived from aerial photographs at a scale of $1: 50000$ acquired in 1956 by the Chinese military geodetic service and a map at a scale of 1:16000 derived from photogrammetric data in 1977.

These topographic maps were first scanned at $600 \mathrm{dpi}$. The $20 \mathrm{~m}$ and $5 \mathrm{~m}$ contour intervals and identified spot heights were then digitized to produce DEMs for 1956 (DEM1956) and 1977 (DEM1977) with a $30 \mathrm{~m}$ cell size. The coordinates of both DEMs were expressed in the Beijing54 Krasovsky coordinate system (datum level is Yellow Sea mean sea level at Qingdao Tidal Observatory in 1956) (BJ54 GEOID). The center and flattening of BJ54 differ from those in CGCS2000. To solve this problem, we used four national trigonometric reference points with BJ54 and CGCS2000 from the State Bureau of Surveying and Mapping of China (SBSM, 2007) to calculate coordinate conversion parameters using a seven-parameter spatial transform model (Wang and others, 2003). All data from the topographic maps were reprojected and transformed into CGCS2000 from BJ54 format. This brought the error to $<0.02 \mathrm{~m}$ for the coordinate conversion using the seven-parameter spatial transform model (Wang and others, 2003).

\section{Remotely sensed images}

We acquired cloud-free satellite images, as indicated in Table 1. The Landsat Enhanced Thematic Mapper Plus (ETM+) image (provided by the Global Land Cover Facility; http://glcf.umiacs.umd.edu/index.shtml) represents values that have been orthorectified to the Universal Transverse Mercator (UTM) coordinate system and referenced to the World Geodetic System 1984 (WGS84). The China-Brazil Earth Resources Satellite-2 (CBERS-2) image was provided by the China Center for Resources Satellite Data and Applications (CRESDA; http://www.cresda.com). It is also in UTM WGS84 with a $19.7 \mathrm{~m}$ resolution. To establish coregistration of the remotely sensed images and topographic maps, the remotely sensed images were co-registered and orthorectified, using topographic maps from 1956 and the DEM1956. Twenty-four ground-control points were taken from the 1:50000 scale map. We then used the DEM1956 to orthorectify the two sets of remotely sensed images. Thus, both remotely sensed images were reprojected into CGCS2000. The registration error was estimated to be $<1$ pixel by overlaying remotely sensed images and topographic maps (Table 1).

\section{Area and length changes}

The outlines of the two glaciers in 1956, 1977, 1999 and 2007 were derived from the two topographic maps, the
Landsat image and a combination of the CBERS-2 image with the field GPS data. We calculated the areas of the two glaciers in these years. To determine the changes in glacier length, $\Delta L$, we measured the length along the flowline between the old and new terminus locations three times, and averaged the values of these measurements.

\section{Thickness changes}

A $1.44 \mathrm{~km}^{2}$ area of $5 Y 432 \mathrm{~A} 1$ and a $0.64 \mathrm{~km}^{2}$ area of $5 Y 432 \mathrm{~A} 5$ were selected to calculate thickness changes between 1956 and 2007. These areas were located in the ablation area of each glacier, between 4360 and $4920 \mathrm{~m}$ a.s.l. (Fig. 2d). Thickness or ice-volume changes were derived from repeated comparisons of the DEMs for different years. Ice-volume changes were calculated by multiplying the change in elevation, $\Delta h$, by the glacier's surface area (Arendt and others, 2006).

Due to the lack of field measurement in 2007 and lack of precision of the DEM1956 measurements in the accumulation area, our work does not cover much of the accumulation area. Also, due to glacier retreat, only a limited part of the ablation area of the glacier was analyzed for iceelevation change (Fig. 2d).

\section{Analysis of horizontal errors}

The horizontal error in glacier extent is controlled by the image resolution (Williams and others, 1997) and the coregistration error (Hall and others, 2003; Silverio and Jaquet, 2005; Ye and others, 2006). According to Ye and others' (2006) derivation from position measurements of glacier fronts using multitemporal images, the uncertainties in our glacier tongue measurements were $10.3 \mathrm{~m}$ between 1956 and 1977, $28.1 \mathrm{~m}$ between 1977 and 1999, $45.4 \mathrm{~m}$ between 1999 and 2007, and $37.1 \mathrm{~m}$ between 1956 and 2007. These values were calculated using

$$
\mathrm{UN}=\sqrt{\sum_{1}^{n} \lambda^{2}}+\sqrt{\sum_{1}^{n} \varepsilon^{2}},
$$

where $U N$ is the uncertainty error, $\lambda$ is the original pixel resolution of each image, $\varepsilon$ is the registration error of each image to the topographic map and $n=2$.

We also calculated the uncertainty in our estimation of glacier area using the methods of Hall and others (2003) and Ye and others (2006). Because the uncertainty $\left(0.01 \mathrm{~km}^{2}\right)$ was smaller than the last significant value of our area estimates, we have ignored this uncertainty in our discussion.

\section{Analysis of vertical errors}

Table 1 presents independent errors of the DEM data sources. The DEM1956 model, which is derived from the 1956 topographic map, is the largest source of systematic error in our analysis, due to problems with its small geometric resolution. In order to calculate the elevation differences between the glacier surfaces in 1956, 1977 and 2007 , we selected six random points in surrounding nonglacierized areas at elevations below $4600 \mathrm{~m}$, with a slope of $<15^{\circ}$, and compared the results among the DEMs. This revealed a mean difference of $7.2 \mathrm{~m}$ (with a standard deviation of $5.4 \mathrm{~m}$ ). However, we did not calculate systematic errors, as we lack sufficient information to quantify their magnitude. Instead, we use the maximum errors for each data source. 

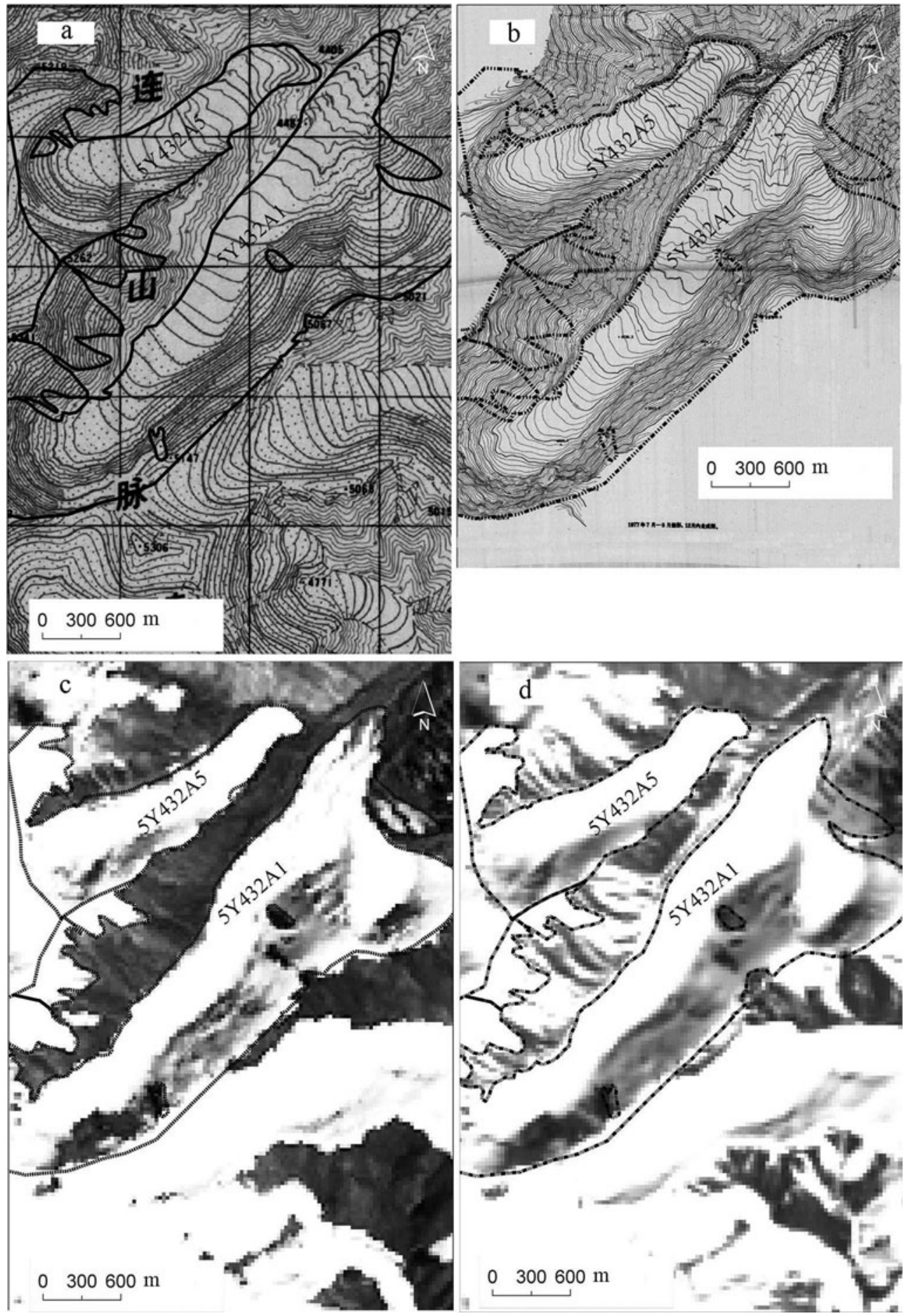

Fig. 3. Delineation of the margins of 5Y432A1 and 5Y432A5 from 1956 to 2007, plotted for four years: (a) topographic map in 1956; (b) topographic map derived from photogrammetry in 1977; (c) Landsat ETM+ for 1999; (d) CBERS-2 in 2007.

Table 2. Changes in glacier area and length for the two glaciers from 1956 to 2007

\begin{tabular}{|c|c|c|c|c|c|}
\hline Name & Glacier change & $1956-77$ & 1977-99 & 1999-2007 & 1956-2007 \\
\hline \multirow[t]{4}{*}{$5 Y 432 \mathrm{~A} 1$} & Change in area (\%) & -0.2 & -2.2 & -1.6 & -4.1 \\
\hline & Change in area $\left(\% \mathrm{a}^{-1}\right)$ & -0.01 & -0.10 & -0.20 & -0.08 \\
\hline & Change in length $(\mathrm{m})$ & $-41.5 \pm 10.3$ & $-141.8 \pm 28.1$ & $-84 \pm 45.4$ & $-266.5 \pm 37.1$ \\
\hline & Change in length $\left(\mathrm{m} \mathrm{a}^{-1}\right)$ & $-2.0 \pm 0.5$ & $-6.4 \pm 1.3$ & $-10.5 \pm 5.7$ & $-5.2 \pm 0.73$ \\
\hline \multirow[t]{4}{*}{ 5Y432A5 } & Change in area (\%) & -0.6 & -13.6 & -2.1 & -15.9 \\
\hline & Change in area $\left(\% \mathrm{a}^{-1}\right)$ & -0.03 & -0.62 & -0.26 & -0.31 \\
\hline & Change in length (m) & $-77.2 \pm 10.3$ & $-60.3 \pm 28.1$ & $-49 \pm 45.4$ & $-181.4 \pm 37.1$ \\
\hline & Change in length $\left(\mathrm{m} \mathrm{a}^{-1}\right)$ & $-3.7 \pm 0.5$ & $-2.7 \pm 1.3$ & $-6.1 \pm 5.7$ & $-3.6 \pm 0.73$ \\
\hline
\end{tabular}




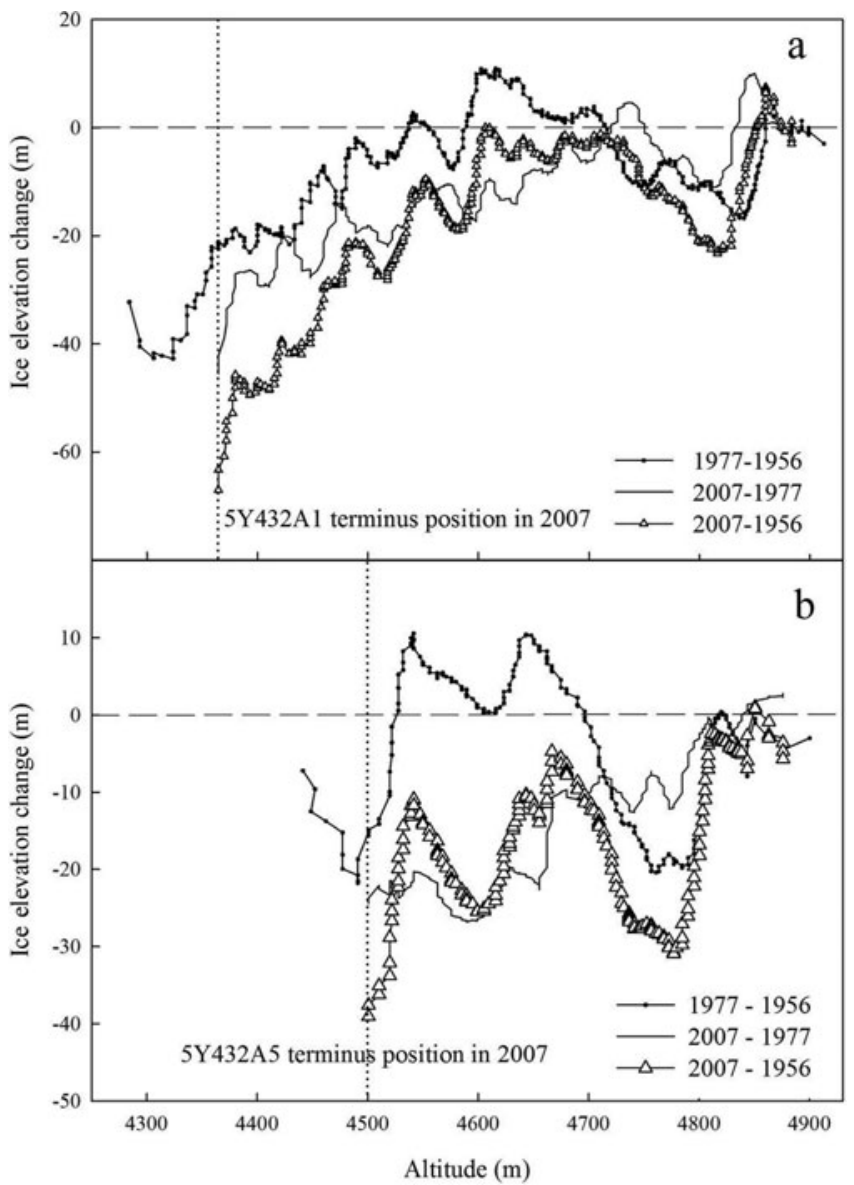

Fig. 4. Ice-elevation changes as a function of altitude on (a) 5Y432A1 and (b) 5Y432A5, from topographic maps (1956, 1977) and GPS-RTK (2007) DEMs.

\section{RESULTS}

\section{Areal and frontal changes}

Our analysis shows that both glaciers 5Y432A1 and $5 Y 432 \mathrm{~A} 5$ decreased in area, by $4.1 \%$ and $15.9 \%$ respectively, between 1956 and 2007 (Fig. 3; Table 2). The greatest rate of area change occurred between 1977 and 1999, during which time the glaciers shrank by about $2.2 \%$ and $13.6 \%$ respectively.

Comparison of the terminus positions (Table 2) shows that 5Y432A 1 and 5Y432A 5 retreated over the total study period by $266.5 \pm 37.1 \mathrm{~m}\left(5.2 \pm 0.73 \mathrm{ma}^{-1}\right)$ and $181.4 \pm 37.1 \mathrm{~m}$ $\left(3.6 \pm 0.73 \mathrm{~m} \mathrm{a}^{-1}\right)$ respectively. This retreat accelerated after 1999. Table 2 also shows that the retreat rates of 5Y432A1 over the periods 1956-77, 1977-99 and 1999-2007 were 2.0, 6.4 and $10.5 \mathrm{ma}^{-1}$ respectively, while the retreat rates over the same periods for 5Y432A5 were 3.7, 2.7 and $6.1 \mathrm{~m} \mathrm{a}^{-1}$ respectively, i.e. between 1999 and 2007 the rate of retreat of both glaciers accelerated markedly.

\section{Ice-elevation changes since 1956}

When DEM2007 and DEM1956 are compared, we observe strong thinning in the lower sections $(<4600 \mathrm{~m}$ a.s.l.) of both glaciers (Fig. 4). The ice elevation decreased by $\sim 10-20 \mathrm{~m}$ between 4610 and $4710 \mathrm{~m}$ a.s.I. for 5Y432A 1 and between 4630 and $4670 \mathrm{ma.s.l}$. for 5Y432A5, yet no significant elevation changes are evident above $4870 \mathrm{~m}$ for 5 Y432A 1 or $4820 \mathrm{~m}$ for 5 Y432A5. Figure 5 shows all the measured ice-elevation changes from 1956 to 2007. The largest amount of ice thinning is observed at a pit in 5Y432A1, where the maximum thinning rates were $1.8 \mathrm{~m} \mathrm{a}^{-1}$ between 1956 and 2007 (Fig. 5). The largest amount of ice thinning is observed at the frontal tongues of both glaciers, where the maximum rates of thinning for 5Y432A1 and 5Y432A5 were 1.8 and $0.8 \mathrm{~m} \mathrm{a}^{-1}$ respectively, between 1956 and 2007.

When the two intermediate periods are considered separately (by including DEM1977), the data show a thinning at low elevations for both glaciers between 1977 and 2007. However, between 1956 and 1977, from 4585 to $4710 \mathrm{~m}$ a.s.I. for $5 \mathrm{Y} 432 \mathrm{~A} 1$ and between 4550 and $4700 \mathrm{~m}$ a.s.l. for $5 \mathrm{Y} 432 \mathrm{~A} 5$, the data suggest a $1-10 \mathrm{~m}$ thickening. There is little change above $4710 \mathrm{~m}$ for $5 \mathrm{Y} 432 \mathrm{~A} 1$ and $4700 \mathrm{~m}$ for 5 Y $432 \mathrm{~A} 5$.

Table 3 shows the changes in mean ice elevation and volume between the DEM1956, DEM1977 and DEM2007 models. The results of this analysis show that the ice elevation in both glaciers has decreased more rapidly in recent years. Between 1956 and 2007, the ablation regions of 5 Y432A 1 and 5 Y432A5 lost ice volumes of about $2.91 \times 10^{7}$ and $1.08 \times 10^{7} \mathrm{~m}^{3}$ respectively, corresponding to mean thickness decreases of $20.2 \pm 11$ and $16.9 \pm 11 \mathrm{~m}$, i.e. rates of $0.40 \pm 0.22$ and $0.33 \pm 0.22 \mathrm{~m} \mathrm{a}^{-1}$ respectively. 5Y432A1 therefore lost 2.7 times the ice volume lost by 5Y432A5. However, these ice volumes do not include those parts of the glaciers lost due to terminus retreat. Furthermore, elevation changes were not determined for the accumulation areas of the glaciers. The values shown in Table 3 are thus smaller than the actual changes.

Table 3. Changes in ice elevation for the two glaciers from 1956 to 2007

\begin{tabular}{|c|c|c|c|c|c|}
\hline \multirow[t]{2}{*}{ Glacier } & \multirow[t]{2}{*}{ Number of pixels in DEM } & \multirow[t]{2}{*}{ Period } & \multicolumn{2}{|c|}{ Change in ice elevation } & \multirow{2}{*}{$\begin{array}{l}\text { Change in volume } \\
\qquad 10^{7} \mathrm{~m}^{3}\end{array}$} \\
\hline & & & $\mathrm{m}$ & $\mathrm{ma}^{-1}$ & \\
\hline \multirow[t]{4}{*}{ 5Y432A1 } & 4938 & & & & \\
\hline & 1598 & 1956-77 & $-6.8 \pm 11$ & $-0.32 \pm 0.52$ & $-0.98 \pm 1.35$ \\
\hline & 1598 & 1977-2007 & $-12.7 \pm 2$ & $-0.42 \pm 0.06$ & $-1.83 \pm 0.27$ \\
\hline & 1598 & 1956-2007 & $-20.2 \pm 11$ & $-0.40 \pm 0.22$ & $-2.91 \pm 1.35$ \\
\hline \multirow[t]{4}{*}{$5 Y 432 \mathrm{~A} 5$} & 1895 & & & & \\
\hline & 715 & $1956-77$ & $-1.8 \pm 11$ & $-0.09 \pm 0.52$ & $-0.12 \pm 0.55$ \\
\hline & 715 & 1977-2007 & $-15.7 \pm 2$ & $-0.52 \pm 0.06$ & $-1.00 \pm 0.12$ \\
\hline & 715 & 1956-2007 & $-16.9 \pm 11$ & $-0.33 \pm 0.22$ & $-1.08 \pm 0.55$ \\
\hline
\end{tabular}




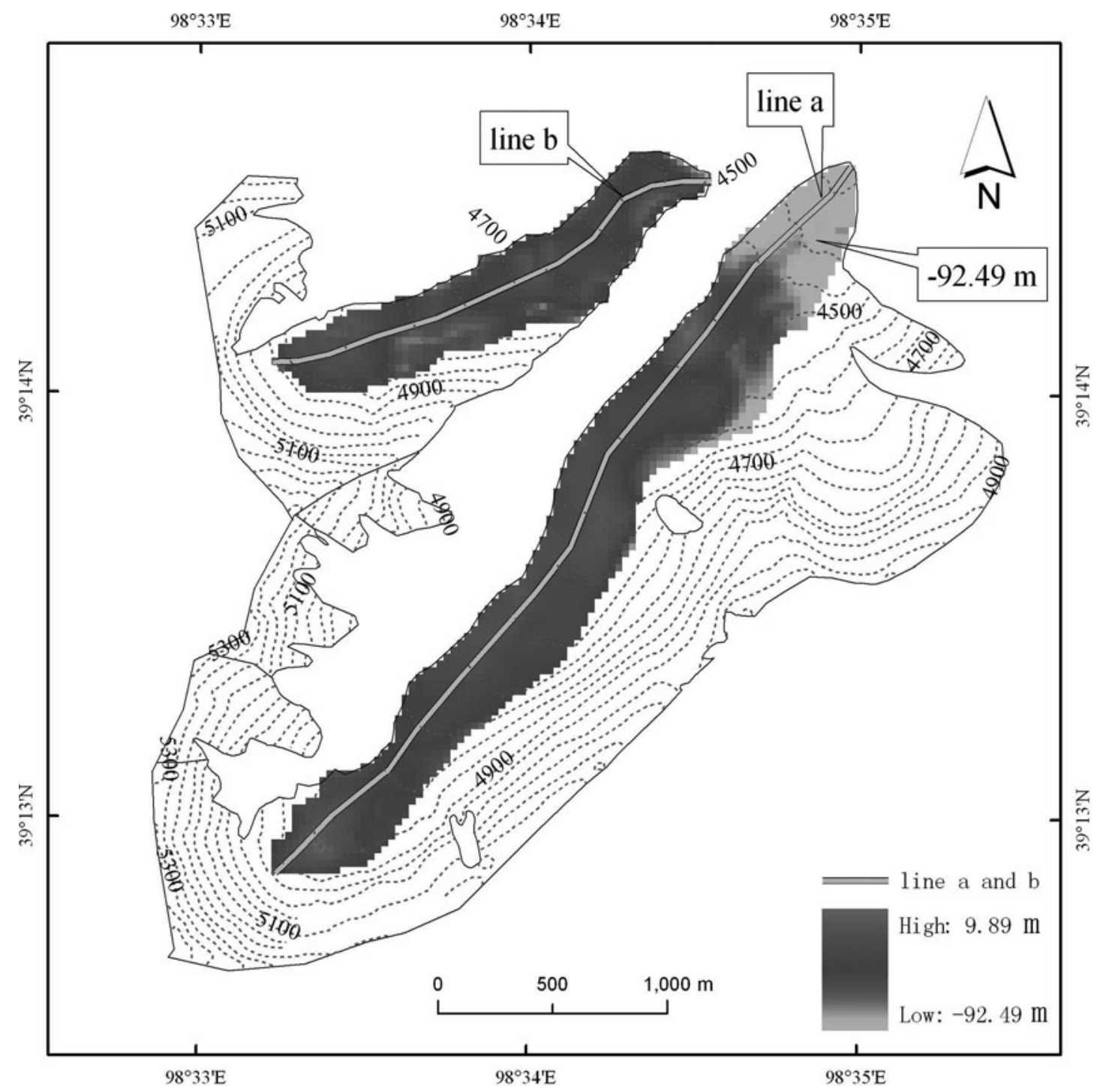

Fig. 5. Changes in surface elevation of the ablation areas of 5Y432A1 and 5Y432A5 from 1956 to 2007. The largest decrease in ice elevation $(92.49 \mathrm{~m})$ occurred at a pit in 5Y432A1. Paths a and b are the routes in Figure $4 \mathrm{a}$ and b respectively.

Co nsidering the two periods separately (by including DEM1977), the ablation regions of 5 Y432A 1 and $5 Y 432 A 5$ lost ice volumes of about $(0.98 \pm 1.35) \times 10^{7}$ and $(0.12 \pm 0.55) \times 10^{7} \mathrm{~m}^{3}$ between 1956 and 1977, corresponding to mean decreases in thickness of $6.8 \pm 11 \mathrm{~m}$ $\left(0.32 \pm 0.52 \mathrm{~m} \mathrm{a}^{-1}\right)$ and $1.8 \pm 11 \mathrm{~m}\left(0.09 \pm 0.52 \mathrm{ma}^{-1}\right)$ respectively. Between 1977 and 2007, 5Y432A1 and 5Y432A5 decreased in volume by totals of $(1.83 \pm 0.27) \times 10^{7}$ and $(1.00 \pm 0.12) \times 10^{7} \mathrm{~m}^{3}$, corresponding to total decreases in ice elevation of $12.7 \pm 2 \mathrm{~m}\left(0.42 \pm 0.06 \mathrm{~m} \mathrm{a}^{-1}\right)$ and $15.7 \pm 2 \mathrm{~m}\left(0.52 \pm 0.06 \mathrm{~m} \mathrm{a}^{-1}\right)$ respectively. Thus, the rates of thinning of both 5Y432A1 and (especially) 5Y432A 5 have increased recently compared to the earlier period.

\section{Reasons for glacier variation}

Glaciers are one of the most distinctive natural indicators of climate change (Hoelzle and others, 2003; Oerlemans, 2005). Glacier variations measured in this study appear to be concurrent with changes of summer air temperature during the past 47 years, according to meteorological data from Tuole weather station $\left(38^{\circ} 48^{\prime} \mathrm{N}, 98^{\circ} 25^{\prime} \mathrm{E}\right.$; 3367 ma.s.l.), which is located about $50 \mathrm{~km}$ southwest of $5 \mathrm{Y} 432 \mathrm{~A} 1$. Figure 6 shows a time series of annual precipitation, summer air temperature (May-September when monthly mean temperature is above $0^{\circ} \mathrm{C}$ ) and annual temperature, along with linear fits and 3 year moving averages. Annual precipitation at Tuole shows a slight increase from 1957 to 2004, which represents favorable climatic conditions for glacier stability (Fig. 6a). However, there has been an increase in summer temperatures through the 1990s (Fig. 6b). This causes higher summer melt rates and corresponding negative glacier mass balance, leading to a decrease in glacier ice elevation, and glacier retreat. Thus, we believe that glacier retreat and thinning during the past 51 years can be attributed primarily to air-temperature rise in the central Qilian Shan.

\section{CONCLUSIONS}

Using topographic maps, remote-sensing images and GPS data, we have monitored changes in glacier length, areal extent and ice elevation during the period 1956-2007 in the central Qilian Shan. Comparisons of DEMs for Yanglonghe glacier No. 1 (5Y432A1) and Yanglonghe glacier No. 5 (5Y432A5) reveal a pattern of retreat, with mean values of 5.2 and $3.6 \mathrm{~m} \mathrm{a}^{-1}$. An accelerating trend in 


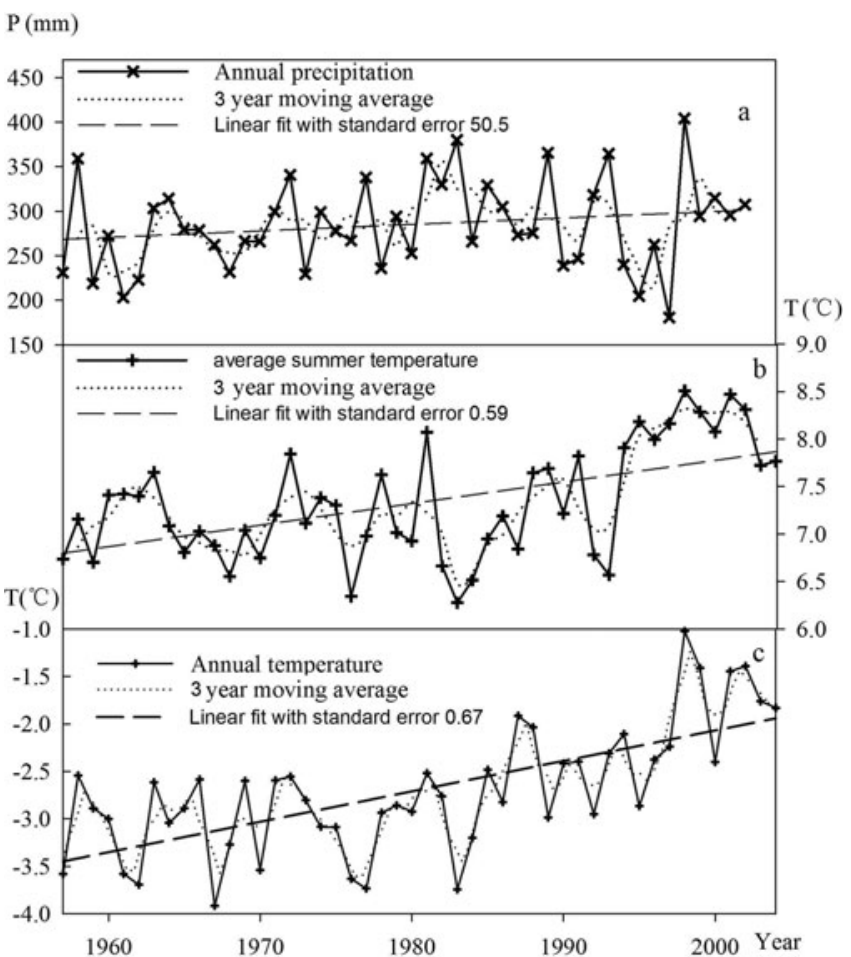

Fig. 6. Changes in (a) annual precipitation ( $\mathrm{mm})$, (b) annual temperature $\left({ }^{\circ} \mathrm{C}\right.$ ) and (c) average summer temperature (MaySeptember) $\left({ }^{\circ} \mathrm{C}\right)$ at the Tuole meteorological station, located about $50 \mathrm{~km}$ from the study area.

the retreat is evident, though the retreat rate of 5Y432A5 was slower $\left(2.7 \mathrm{~m} \mathrm{a}^{-1}\right)$ in 1977-99 than in the periods before and after this time-span. The thinning rates of $5 \mathrm{Y} 432 \mathrm{~A} 1$ and $5 \mathrm{Y} 432 \mathrm{~A} 5$ were $0.40 \pm 0.22 \mathrm{ma}^{-1}$ and $0.33 \pm 0.22 \mathrm{ma}^{-1}$ respectively, from 1956 to 2007 , and were greater in 1977-2007 than in 1956-77.

The results show that 5 Y432A5 lost proportionately more area $(15.9 \%$ vs $4.1 \%)$ and proportionately more length $(7.3 \%$ vs $4.6 \%$ ) than 5 Y $432 \mathrm{~A} 1.5 \mathrm{Y} 432 \mathrm{~A} 1$ exhibited greater absolute retreat $(266.5 \mathrm{~m}$ vs $181.4 \mathrm{~m}$ ) but less relative retreat $(4.6 \%$ vs $7.3 \%$ ) over the study period. Our data also show that the ice volume lost by 5 Y432A1 $\left((-2.91 \pm 1.35) \times 10^{7} \mathrm{~m}^{3}\right.$ ice $)$ was 2.7 times that lost by 5 Y $432 \mathrm{~A} 5\left((-1.08 \pm 0.55) \times 10^{7} \mathrm{~m}^{3}\right.$ ice $)$, suggesting that the larger the glacier, the greater the influence on regional meltwater resources. The past five decades have seen major thinning of the ablation areas of both glaciers, but it will not be possible to determine changes in the accumulation areas until further data are collected.

Climatic records show no significant change in precipitation during the study period, but a significant increase in summer temperature, suggesting that climatic warming is the primary factor responsible for the glacier shrinkage.

\section{ACKNOWLEDGEMENTS}

Special appreciation is due to G. Hart for helpful suggestions. This work was supported by the Ministry of Science and Technology of the People's Republic of China (grant 2006FY110200), the National Natural Science Foundation of China (grant 40601022), the Key Programs of the Chinese Academy of Sciences (grant KZCX2-YW-301) and a grant from the Major State Basic Research Development Program of China (973 Program No. 2007CB411506).

\section{REFERENCES}

Arendt, A. and 7 others. 2006. Updated estimates of glacier volume changes in the western Chugach Mountains, Alaska, and a comparison of regional extrapolation methods. J. Geophys. Res., 111(F3), F03019. (10.1029/2005JF000436.)

Berthier, E. and T. Toutin. 2008. SPOT5-HRS digital elevation models and the monitoring of glacier elevation changes in North-West Canada and South-East Alaska. Remote Sens. Environ., 112(5), 2443-2454.

Berthier, E., Y. Arnaud, D. Baratoux, C. Vincent and F. Rémy. 2004. Recent rapid thinning of the Mer de Glace glacier derived from satellite optical images. Geophys. Res. Lett., 31(17), L17401. (10.1029/2004GL020706.)

Braithwaite, R.J. 2002. Glacier mass balance: the first 50 years of international monitoring. Progr. Phys. Geogr., 26(1), 76-95.

Ding, Y., S. Liu, J. Li and D. Shangguan. 2006. The retreat of glaciers in response to recent climate warming in western China. Ann. Glaciol., 43, 97-105.

Haeberli, W., M. Hoelzle, F. Paul and M. Zemp. 2007. Integrated monitoring of mountain glaciers as key indicators of global climate change: the European Alps. Ann. Glaciol., 46, 150-160.

Hall, D.K., K.J. Bayr, W. Schöner, R.A. Bindschadler and J.Y.L. Chien. 2003. Consideration of the errors inherent in mapping historical glacier positions in Austria from ground and space (1893-2001). Remote Sens. Environ., 86(4), 566-577.

Hoelzle, M., W. Haeberli, M. Dischl and W. Peschke. 2003. Secular glacier mass balances derived from cumulative glacier length changes. Global Planet. Change, 36(4), 295-306.

Howat, I.M., I.R. Joughin and T.A. Scambos. 2007. Rapid changes in ice discharge from Greenland outlet glaciers. Science, 315(5818), 1559-1561

Kääb, A., F. Paul, M. Maisch, M. Hoelzle and W. Haeberli. 2002. The new remote-sensing-derived Swiss glacier inventory: II. First results. Ann. Glaciol., 34, 362-366.

Kargel, J.S. and 16 others. 2005. Multispectral imaging contributions to global land ice measurements from space. Remote Sens. Environ., 99(1-2), 187-219.

Kaser, G., J.G. Cogley, M.B. Dyurgerov, M.F. Meier and A. Ohmura. 2006. Mass balance of glaciers and ice caps: consensus estimates for 1961-2004. Geophys. Res. Lett., 33(19), L19501. (10.1029/2006GL027511.)

King, M. 2004. Rigorous GPS data-processing strategies for glaciological applications. J. Glaciol., 50(171), 601-607.

Liu, S., W. Sun, Y. Shen and G. Li. 2003. Glacier changes since the Little Ice Age maximum in the western Qilian Shan, northwest China, and consequences of glacier runoff for water supply. J. Glaciol., 49(164), 117-124.

Liu, S. and 7 others. 2006. Glacier retreat as a result of climate warming and increased precipitation in the Tarim river basin, northwest China. Ann. Glaciol., 43, 91-96.

Meier, M.F. and 7 others. 2007. Glaciers dominate eustatic sealevel rise in the 21st century. Science, 317(5841), 1064-1067.

Oerlemans, J. 2005. Extracting a climate signal from 169 glacier records. Science, 308(5722), 675-677.

Paul, F., A. Kääb, M. Maisch, T. Kellenberger and W. Haeberli. 2002. The new remote-sensing-derived Swiss glacier inventory: I. Methods. Ann. Glaciol., 34, 355-361.

Paul, F., A. Kääb, M. Maisch, T. Kellenberger and W. Haeberli. 2004. Rapid disintegration of Alpine glaciers observed with satellite data. Geophys. Res. Lett., 31(21), L21402. (10.1029/ 2004GL020816.)

Rignot, E., A. Rivera and G. Casassa. 2003. Contribution of the Patagonian icefields of South America to sea level rise. Science, 302(5644), 434-437.

Rivera, A. and G. Casassa. 1999. Volume changes on Pio XI glacier, Patagonia: 1975-1995. Global Planet. Change, 22(1-4), 233-244. 
Rivera, A., G. Casassa, J.L. Bamber and A. Kääb. 2005. Iceelevation changes of Glaciar Chico, southern Patagonia, using ASTER DEMs, aerial photographs and GPS data. J. Glaciol., 51(172), 105-112.

Shangguan, D. and 9 others. 2006. Monitoring the glacier changes in the Muztag Ata and Konggur mountains, east Pamirs, based on Chinese Glacier Inventory and recent satellite imagery. Ann. Glaciol., 43, 79-85.

Silverio, W. and J.M. Jaquet. 2005. Glacial cover mapping (19871996) of the Cordillera Blanca (Peru) using satellite imagery. Remote Sens. Environ., 95(3), 342-350.

State Bureau of Surveying and Mapping of China (SBSM). 2007. Technical specifications for producing 1:10000 and 1:50000 digital elevation models. Beijing, Standards Press of China. (Standard No. CH/T 1015.1-2007.)

Wang, J.X., J. Wang and C.P. Lu. 2003. Problem of coordinate transformation between WGS-84 and BEIJING 54. IJ. Geod. Geodyn.], 23(3), 70-73. [In Chinese.]

Wang, Z.T., C. Liu, G. You, J. Pu, H. Yang and P.Y. Tian, eds. 1981. Glacier inventory of China I. Qilian Mountains. Beijing, Science
Press. Academia Sinica, Lanzhou Institute of Glaciology and Cryopedology. [In Chinese.]

Williams, R.S., Jr, D.K. Hall and J.Y.L. Chien. 1997. Comparison of satellite-derived with ground-based measurements of the fluctuations of the margins of Vatnajökull, Iceland, 1973-92. Ann. Glaciol., 24, 72-80.

Xie, Z., G. Wu and L. Wang. 1985. Recent advance and retreat of glaciers in Qilian Mountains. In Mem. Lanzhou Inst. Glaciol. Cryopedol., 5, 82-90. [In Chinese.]

Yao, T., S. Liu, J. Pu, Y. Shen and A. Lu. 2004. Recent retreat of high Asian glaciers and the impact to water resource of northwest China. Sci. China D, 34(6), 535-543.

$\mathrm{Ye}, \mathrm{B}$. and 6 others. 2005. The Urumqi River source Glacier No. 1, Tianshan, China: changes over the past 45 years. Geophys. Res. Lett., 32(21), L21504. (10.1029/ 2005GL024178.)

Ye, Q., S. Kang, F. Chen and J. Wang. 2006. Monitoring glacier variations on Geladandong mountain, central Tibetan Plateau, from 1969 to 2002 using remote-sensing and GIS technologies. J. Glaciol., 52(179), 537-545.

MS received 7 May 2009 and accepted in revised form 13 April 2010 